\title{
Does glucocorticoid exposure explain the association between metabolic dysfunction and tendinopathy?
}

\author{
Trevor Lewis ${ }^{1}$, Eva Zeisig ${ }^{2}$ and Jamie E Gaida ${ }^{3}$ \\ ${ }^{1}$ Physiotherapy Department, Aintree University Hospital NHS Foundation Trust, Liverpool, UK \\ ${ }^{2}$ Department of Surgical and Perioperative Sciences, Umeå Univerisity, Umeå, Sweden \\ ${ }^{3}$ University of Canberra Research Institute for Sport and Exercise (UCRISE), Canberra, Australian Capital Territory, Australia
}

Correspondence should be addressed to T Lewis: trevorlewissky@sky.com

\begin{abstract}
Background: While metabolic health is acknowledged to affect connective tissue structure and function, the mechanisms are unclear. Glucocorticoids are present in almost every cell type throughout the body and control key physiological processes such as energy homeostasis, stress response, inflammatory and immune processes, and cardiovascular function. Glucocorticoid excess manifests as visceral adiposity, dyslipidemia, insulin resistance, and type 2 diabetes. As these metabolic states are also associated with tendinopathy and tendon rupture, it may be that glucocorticoids excess is the link between metabolic health and tendinopathy.

Objective: To synthesise current knowledge linking glucocorticoid exposure to tendon structure and function.

Methods: Narrative literature review.

Results: We provide an overview of endogenous glucocorticoid production, regulation, and signalling. Next we review the impact that oral glucocorticoid has on risk of tendon rupture and the effect that injected glucocorticoid has on resolution of symptoms. Then we highlight the clinical and mechanistic overlap between tendinopathy and glucocorticoid excess in the areas of visceral adiposity, dyslipidemia, insulin resistance and type 2 diabetes. In these areas, we highlight the role of glucocorticoids and how these hormones might underpin the connection between metabolic health and tendon dysfunction. Conclusions: There are several plausible pathways through which glucocorticoids might mediate the connection between metabolic health and tendinopathy.
\end{abstract}

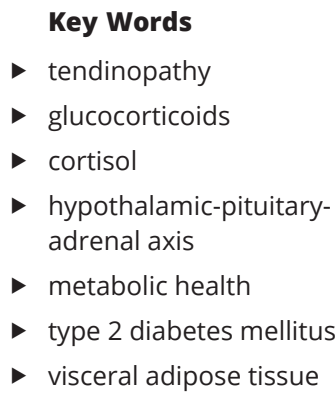

Endocrine Connections (2020) 9, R36-R46

\section{Introduction}

The mechanisms linking obesity and poor metabolic health to increased tendinopathy risk remain unclear (1). Among athletes, mechanical load associated with high training volumes and hard training surface can trigger tendinopathy (2). Similarly, rapid increases in training volume or intensity can exceed tendon capacity (3). However, tendinopathy in sedentary individuals accounts for almost one-third of cases (4). Tendinopathy and tendon rupture are associated with obesity and associated metabolic conditions, such as insulin resistance (5), diabetes (6), hypercholesterolaemia (7), statins (8), abdominal fat (9), the sympathetic nervous system (10, 11 ), and corticosteroid use (12).

Glucocorticoids are a class of steroid hormones present in almost every cell of the body and are essential for survival (13). Glucocorticoid release is regulated by 
the hypothalamic-pituitary-adrenal (HPA) axis. The suprachiasmatic nucleus of the hypothalamus releases corticotrophin-releasing hormone (CRH) into the hypothalamic-pituitary portal circulation in response to internal and external signals (14). This triggers the anterior lobe of the pituitary gland to release adrenocorticotrophic hormone (ACTH) into the circulation (14). At the adrenal gland, ACTH stimulates production and release of glucocorticoid into the circulation (15). In each 24-h period there are 7-13 glucocorticoid pulses, collectively these are referred to as the ultradian rhythm (16). The amplitude of these pulses varies throughout the day to create a 24-h diurnal rhythm that is superimposed upon the shorter ultradian rhythm (16). This continuous dynamic equilibrium is maintained by delayed feedback and feedforward mechanisms within the HPA (16). Interestingly, there is an additional level of control whereby the suprachiasmatic nucleus of the hypothalamus acts via the sympathetic nervous system to set the sensitivity of the adrenal cortex to the incoming hormonal signal (17).

Glucocorticoid hormones regulate an array of physiologic processes including energy homeostasis, inflammatory and immune responses, cardiovascular function, reproduction, and cognition $(13,15)$. While glucocorticoid function has been extensively studied in the context of the stress response, it is important to remember that the HPA axis is only one of many stressresponsive systems within the body $(15,18)$. A stressor is a real or perceived threat to homeostasis or well-being. This definition, therefore, includes both physiological and psychological stressors. Acute activation of the HPA axis generates a glucocorticoid spike, which mobilises energy reserves (18) by increasing gluconeogenesis in the liver and inhibiting insulin production in the pancreas (19). With increased energy reserves available, the individual is able to enact an appropriate response to the stressor (18).

Chronic stress disrupts the pulsatile pattern of glucocorticoid release and results in a number of maladaptive responses. This includes obesity, altered fat distribution, insulin resistance, type 2 diabetes, and increased rates of cardiovascular disease (20). Therefore, chronic glucocorticoid exposure causes many of the same metabolic states that have been associated with tendinopathy (Table 1). There is also a close connection between glucocorticoid excess and over-activity of the sympathetic nervous system (21), which has also been linked to tendinopathy $(10,11)$. This review will explore the hypothesis that glucocorticoid exposure could explain the association between metabolic dysfunction and tendinopathy (Fig. 1).

\section{Glucocorticoid receptors}

Glucocorticoids mainly act via the cytoplasmic glucocorticoid receptor (22). Upon activation by glucocorticoid the glucocorticoid receptor undergoes a conformational change. This change triggers nuclear translocation. Inside the nucleus, the glucocorticoid receptor interacts with the DNA and other proteins to control gene expression and transcription (22). Glucocorticoids can activate or repress up to $20 \%$ of the human genome via this pathway.

\section{Cushing's syndrome patients have increased tendon rupture risk}

Cushing's syndrome is a clinical condition resulting from chronic glucocorticoid excess (23). In addition to a multitude of clinical manifestations, sufferers of Cushing's syndrome are predisposed to Achilles tendon rupture (24). It is noteworthy that many of the clinical manifestations of Cushing's syndrome (15) overlap with the metabolic features that have been associated with tendinopathy (e.g. increased abdominal fat accumulation, dyslipidemia, and insulin resistance - Table 1).

Individuals with Cushing's syndrome have a $2-5$ fold increase in visceral fat as well as wasting of peripheral subcutaneous depots $(20,23)$. This results in the characteristic body shape that is associated with Cushing's syndrome (23). Further evidence of a mechanistic link between glucocorticoid excess and visceral adiposity is the normalisation of fat distribution following successful treatment of Cushing's syndrome (20).

\section{Exogenous oral glucocorticoids and their effects on tendon}

Numerous published case studies and pharmacovigilance databases report tendon ruptures in association with corticosteroid use (25). A recent case-control database study of 8000 cases and 33,000 controls found that oral but not inhaled corticosteroids increase risk of Achilles and biceps tendon rupture (26). The adjusted odds ratio for tendon rupture with current corticosteroid use was 2.07 (95\% CI 1.79 to 2.38 ) with even higher risk seen within first month of initiating therapy where the odds ratio was 3.82 (95\% CI 1.94 to 7.53). Furthermore, there was a dose-response effect of increasing risk when comparing those on less than $5 \mathrm{mg}$ prednisolone, those on 5-10 mg prednisolone, and those on greater than $10 \mathrm{mg}$ prednisolone. Finally, there was a steady decline in risk upon cessation of therapy (26).

This work is licensed under a Creative Commons Attribution-NonCommercial-NoDerivatives 4.0 Internationab sicense.ifica . com at 04/26/2023 08:38:42AM 
Table 1 Major studies investigating the major metabolic causes of tendinopathy.

\begin{tabular}{|c|c|c|c|c|c|}
\hline Study & $\begin{array}{l}\text { Metabolic factor } \\
\text { related to } \\
\text { tendinopathy } \\
\text { investigated }\end{array}$ & $\begin{array}{l}\text { Age range/ } \\
\text { mean age }\end{array}$ & Sample size & $\begin{array}{l}\text { Male (M)I } \\
\text { female (F) }\end{array}$ & Results \\
\hline Gaida et al. (1) & Adiposity & $\begin{array}{l}\text { Not } \\
\text { specified }\end{array}$ & $\begin{array}{l}\text { Systematic } \\
\text { review }(19,949 \\
\text { individuals) }\end{array}$ & $\begin{array}{l}9,536 \mathrm{M} \\
10,413 \mathrm{~F}\end{array}$ & $\begin{array}{l}42 \text { sub-populations identified, } 18 \text { of which } \\
\text { showed elevated adiposity to be } \\
\text { associated with tendon injury ( } 43 \%) \text {. } \\
\text { Sensitivity analyses indicated positive } \\
\text { findings amongst clinical patients ( } 81 \% \\
\text { positive) and also case-control studies } \\
\text { ( } 77 \% \text { positive) }\end{array}$ \\
\hline Gaida et al. (9) & Bodily fat distribution & $\begin{array}{l}\text { Range: } \\
\text { 18-75 yrs. } \\
\text { Mean age } \\
\text { not stated }\end{array}$ & 298 & $127 \mathrm{M}, 171 \mathrm{~F}$ & $\begin{array}{l}\text { Men with Achilles tendon pathology were } \\
\text { older }(50.9+10.4,36.3+11.3, P<0.001) \\
\text { and had a central fat distribution. Women } \\
\text { with tendon pathology were older } \\
(47.4+10.0,36.0+10.3, P=0.008) \text { and had } \\
\text { a peripheral fat distribution. } \\
\text { An interaction between age and waist } \\
\text { circumference was observed among men } \\
\text { (waist circumference }>83 \mathrm{~cm} \text { ) }\end{array}$ \\
\hline Gaida et al. (5) & $\begin{array}{l}\text { Comparison of lipid } \\
\text { profiles between } \\
\text { subjects with AT } \\
\text { and matched } \\
\text { controls }\end{array}$ & $\begin{array}{l}\text { Age range } \\
27-62 \text { yrs } \\
\text { Mean age } \\
47.9+9.4\end{array}$ & 60 & $32 \mathrm{M}, 28 \mathrm{~F}$ & $\begin{array}{l}\text { AT patients showed evidence of } \\
\text { dyslipidaemia; higher TGs }(P=0.039) \text {, } \\
\text { lower HDL-C }(P=0.016) \text { and higher TG/ } \\
\text { HDL-C ratio }(P=0.036) \text { and elevated } \\
\text { apolipoprotein B }(P=0.017)\end{array}$ \\
\hline Tilley et al. (7) & $\begin{array}{l}\text { Serum cholesterol } \\
\text { and statin use }\end{array}$ & $\begin{array}{l}\text { Not } \\
\text { specified }\end{array}$ & $\begin{array}{l}\text { Systematic } \\
\text { review. } \\
17 \text { studies ( } 2612 \\
\text { participants) }\end{array}$ & $\begin{array}{l}\text { Not } \\
\text { specified }\end{array}$ & $\begin{array}{l}\text { Significantly higher levels of TC, LDL, TG } \\
\text { and VLDL-C in individuals with tendon } \\
\text { pain/abnormality. Two studies found a } \\
\text { positive relationship between tendon } \\
\text { thickness and lipid levels. Statin use } \\
\text { associated with ATR in women but not } \\
\text { men. }\end{array}$ \\
\hline Adams et al. (49) & $\begin{array}{l}\text { Lipid deposition in } \\
\text { cadaveric human } \\
\text { arteries, tendons } \\
\text { and fascia }\end{array}$ & $5-88$ yrs & 106 & $\begin{array}{l}\text { Not } \\
\text { specified }\end{array}$ & $\begin{array}{l}\text { Lipids (cholesterol esters) were found to } \\
\text { be deposited in human tendons from the } \\
\text { age of } 15 \text { yrs old }\end{array}$ \\
\hline $\begin{array}{l}\text { Finlayson \& } \\
\text { Woods (50) }\end{array}$ & $\begin{array}{l}\text { Lipid deposition in } \\
\text { the Achilles tendon } \\
\text { of cadavers }\end{array}$ & $0-83$ yrs & 50 & $33 \mathrm{M}, 17 \mathrm{~F}$ & $\begin{array}{l}\text { Lipids (esterified cholesterol) found in 90\% } \\
\text { of Achilles specimens }\end{array}$ \\
\hline $\begin{array}{l}\text { Ozgurtas } \\
\text { et al. (51) }\end{array}$ & $\begin{array}{l}\text { Serum lipid profiles } \\
\text { in individuals with } \\
\text { ATR compared to } \\
\text { uninjured controls }\end{array}$ & $\begin{array}{l}\text { Mean age } \\
25.7 \text { yrs }\end{array}$ & 47 & $41 \mathrm{M}, 6 \mathrm{~F}$ & $\begin{array}{l}\text { TC and low-density lipoprotein cholesterol } \\
\text { (LDL-C) concentrations higher in ATR } \\
\text { patients }(P<0.001) \text { and also TG and } \\
\text { VLDL-C }(P<0.05) \text {. HDL was lower than in } \\
\text { the control group }(P<0.05)\end{array}$ \\
\hline Lin et al. (52) & $\begin{array}{l}\text { Diabetes, } \\
\text { hyperlipidaemia } \\
\text { and statin use in } \\
\text { RCD }\end{array}$ & $48.8+14.0$ & 498,678 & $\begin{array}{r}253,401 \mathrm{M} \\
245,227 \mathrm{~F}\end{array}$ & $\begin{array}{l}\text { Either diabetes or hyperlipidaemia alone } \\
\text { was a risk factor for RCD (both to } \\
P<0.0001 \text { ). Statins were shown to be } \\
\text { protective against RCD }\end{array}$ \\
\hline Ranger et al. (6) & $\begin{array}{l}\text { Diabetes mellitus } \\
\text { and tendinopathy }\end{array}$ & $\begin{array}{l}\text { Not } \\
\text { specified }\end{array}$ & $\begin{array}{l}31 \text { studies. } \\
\text { Systematic } \\
\text { review }\end{array}$ & $\begin{array}{l}\text { Not } \\
\text { specified }\end{array}$ & $\begin{array}{l}17 \text { studies showed that tendinopathy was } \\
\text { more prevalent in people with } \mathrm{DM}(\mathrm{Cl} \\
2.71 \text { to } 4.97), 5 \text { studies showed the } \\
\text { converse was true ( } \mathrm{Cl} 1.10 \text { to } 1.49) \text {, } \\
\text { people with tendinopathy and DM had a } \\
\text { longer duration of DM than those with } \\
\text { DM alone }(\mathrm{Cl} 4.15 \text { to } 6.36) \text {. Patients with } \\
\text { DM had thicker tendons than controls ( } \mathrm{Cl} \\
0.47 \text { to } 1.12)\end{array}$ \\
\hline
\end{tabular}

AT, Achilles tendinopathy; DM, diabetes mellitus; ATR, Achilles tendon rupture; HDL, high density lipoprotein; LDL-C, low density lipoprotein cholesterol; $R C D$, rotator cuff disease; TC, total cholesterol; TG, triglyceride; VLDL-C, very low density lipoprotein cholesterol.

https://ec.bioscientifica.com https://doi.org/10.1530/EC-19-0555 (c) 2020 The authors Published by Bioscientifica Ltd

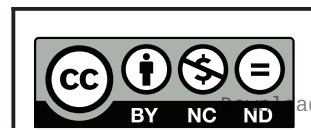

This work is licensed under a Creative Commons Attribution-NonCommercial-NoDerivatives 4.0 Internationad kicense.ifica com at $04 / 26 / 2023$ 08:38:42AM 


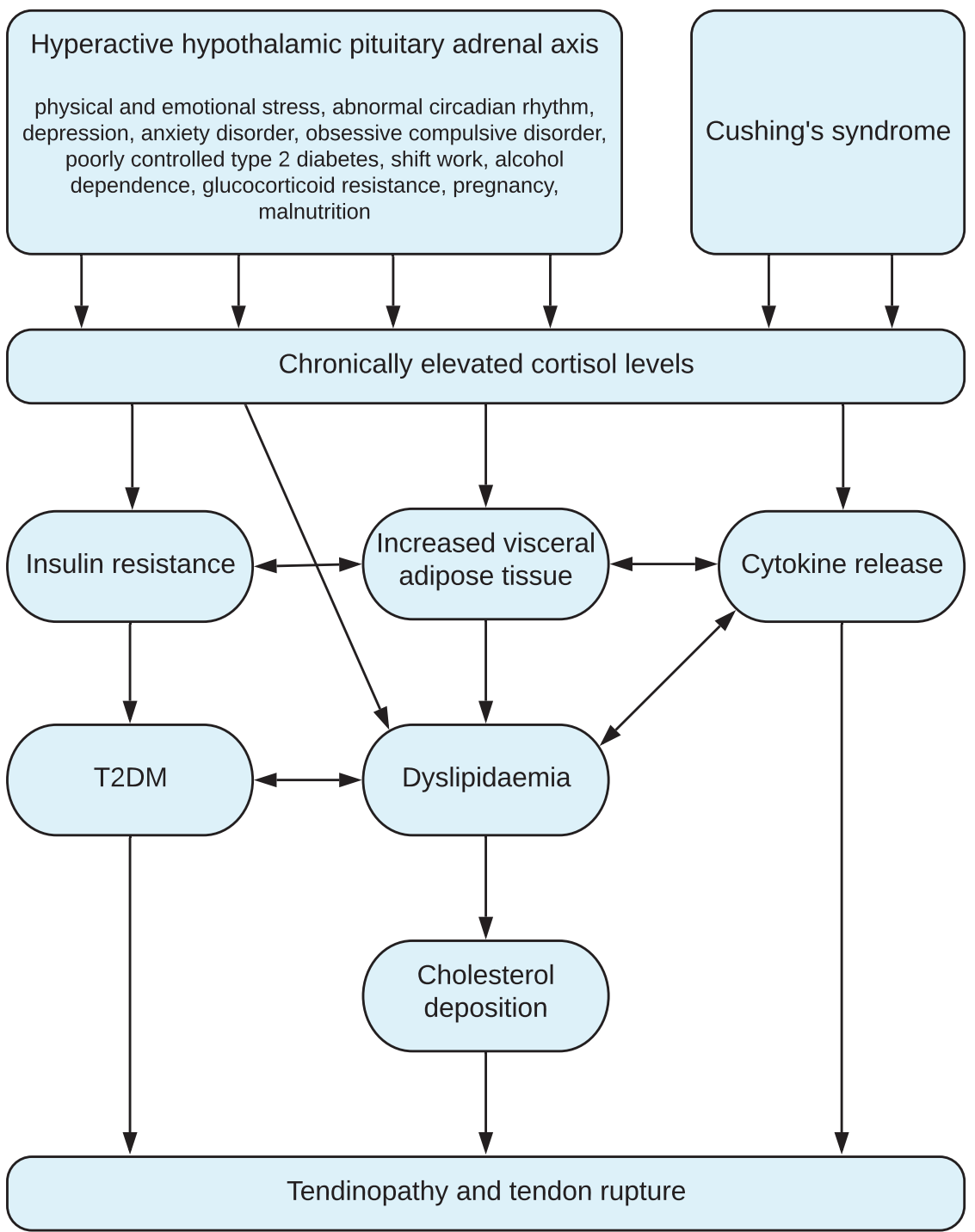

Figure 1

Flowchart illustrating the connections through which glucocorticoid levels might increase tendinopathy risk.
In animal models, systemic exposure to glucocorticoids alters tendon mechanical properties, collagen crosslinking, and collagen fiber size distribution. Taguchi and colleagues administered daily subcutaneous prednisolone injections to rats for 8 weeks. Maximum tensile strength was decreased by $15 \%$, collagen content was decreased by $5 \%$, immature collagen cross-links were decreased by $35 \%$, and mature collagen cross-links were decreased by $30 \%$ (27). Mean collagen fiber diameter was reduced by $15 \%$ and fiber size distribution was shifted such that larger fibers were rarer (27).

There is much debate regarding the mechanism through which glucocorticoid exposure weakens or damages tendon. In vitro studies show that across a range of doses, dexamethasone decreases cell viability, decreases cell proliferation, decreases collagen formation, and increases reactive oxygen species formation (28).
When exposed to glucocorticoid, cultured tenocytes tend to lose characteristic features and genetic markers typical of healthy tenocytes (29). Stimulation with dexamethasone showed a dose-dependent reduction in tenocyte phenotype with reduced expression of the scleraxis gene, decreased cell turnover, and decreased expression of the collagen 1, 3 and 14 genes. There results were paralleled in a recent study that further showed these effects could be prevented by co-treatment with vitamin D (30).

\section{Exogenous injected glucocorticoids and their effects on tendon}

Cortisone is a synthetic glucocorticoid that was first injected into a patient in 1948 for the treatment of rheumatoid arthritis with very good effect (22). (c) 2020 The authors Published by Bioscientifica Ltd
This work is licensed under a Creative Commons Attribution-NonCommercial-NoDerivatives 4.0 Internationab sicense.ifica . com at 04/26/2023 08:38:42AM 
Since that time, cortisone has frequently been used to treat painful musculoskeletal diseases including inflammatory arthritis, osteoarthritis, degenerative spinal disease, tenosynovitis and tendinopathy. So much so that, in 2014, over half a million articular glucocorticoid or corticosteroid injections (CSI) were administered within the UK primary care system (31). Earlier generations of clinicians were taught that 'tendinitis' was primarily an inflammatory condition (32), whereas contemporary research has shifted toward a 'degenerative' disease model with the key features of collagen separation, thinning, and disruption without an inflammatory cell infiltrate (33). This dichotomy between primary inflammatory versus primary degenerative is likely an oversimplification with both aspects playing a role $(34,35)$.

Despite the degenerative model of pathology being widely accepted, the use of glucocorticoid injections for their anti-inflammatory effects continues. One histological and immuno-histochemical study (36) compared supraspinatus tendon tissue between subjects receiving surgical rotator cuff repair with those receiving local ultrasound-guided glucocorticoid injection to the shoulder (40 $\mathrm{mg}$ of depomedrone and $4 \mathrm{ml}$ of $2 \%$ lignocaine into the sub-acromial bursa). Interestingly, both surgical and injection groups showed no significant change in the Oxford Shoulder Scale at 7 weeks compared to baseline. In contrast, biopsies revealed vascularity, angiogenesis and nerve growth, which are important in the healing process, only in the surgical repair group. The injection group demonstrated increased glutamate receptor (NMDAR1) expression, which raised concern about the potential for excitotoxic tendon damage.

Another study investigating the treatment of lateral elbow tendinopathy (tennis elbow) compared CSI, physiotherapy and a 'wait and see' approach. Physiotherapy treatment comprising elbow manipulation and exercise displayed a superior effect to both 'wait and see' and CSI at 6 weeks (37). The benefits of corticosteroid injection often reverse after 6 weeks, with high recurrence rates, implying that this treatment should be used with caution in the management of tennis elbow. In this study, one of two medical practitioners treated participants assigned to the CSI group with a local injection to the painful point at the lateral elbow, consisting of $1 \mathrm{~mL}$ of $1 \%$ lidocaine with $10 \mathrm{mg}$ of triamcinolone acetonide. In both of the cited experiments $(36,37)$ the delivered dose of steroid was within the suggested therapeutic range documented in international guidelines (38). For some time there has been evidence that CSI for tendon are effective only in the short term, this evidence extends to tendinopathy in many locations other than the elbow $(33,39)$.

Systematic reviews of the literature regarding glucocorticoid treatment for tendinopathy have revealed both negative clinical effects (39) and negative effects on tendon cells. These effects include reduced cell proliferation, viability and collagen synthesis, while in vivo studies show collagen disorganization and necrosis (31). It has long been established that cortisone injections can predispose tendons to weakening $(40,41)$, it is also well established that both intra- and peri-tendinous corticosteroid injection can precipitate tendon rupture through inhibition of tenocyte proliferation and the reduction in the strength of isolated collagen fascicles (42, $43,44,45)$.

\section{Visceral adiposity}

Glucocorticoid excess preferentially increases visceral fat accumulation (20). Although glucocorticoid exposure causes body-wide insulin resistance, the effect is tissue dependent and adipose tissue insulin sensitivity actually increases, which contributes to adipocyte differentiation and lipid accumulation (20). Similarly, glucocorticoid exposure preferentially increases lipoprotein lipase activity in visceral adipose tissue, which increases uptake of triglycerides and fatty acids into adipocytes leading to increased visceral adiposity (20). Furthermore, glucocorticoid receptor alpha is more highly expressed in adipose tissue and may be another mechanism linking glucocorticoid exposure to visceral adiposity (20).

Visceral fat accumulation is associated with tendinopathy $(1,9)$. A meta-analysis of 20,000 individuals with and without tendinopathy found that elevated adiposity was frequently associated with tendinopathy (1). This association was seen across studies that used BMI as well as those that used waist circumference and waist to hip ratios. While BMI reflects total adipose tissue, waist circumference and waist-to-hip ratio assess adipose tissue distribution (46). These later measures are good proxies for visceral fat accumulation and are important clinical markers of cardiovascular disease risk (46). The association with visceral fat was seen for both lower limb weight bearing tendons as well as non-weight bearing tendons. Therefore, the association cannot be explained solely by increased mechanical loading. Visceral fat secretes proinflammatory cytokines including TNF-alpha, IL-6 and IL-1beta (47), and these cytokines have been implicated in the pathophysiology of tendon pathology and 
rupture (35) suggesting that these particular metabolic factors released by or associated with visceral adiposity (47) increase an individual's susceptibility to tendinopathy. Given that glucocorticoid exposure increases visceral fat deposition (20) there appears to be a link between this exposure and tendinopathy.

\section{Dyslipidemia}

Glucocorticoid excess induces dyslipidemia (15). As well as causing dyslipidemia via increased visceral adiposity (20, 23), cortisol also affects lipid processing pathways in the liver (48). These include enhanced lipolysis, altered free fatty acid processing, and hepatic fat accumulation (48).

Dyslipidemia is associated with tendinopathy $(5,7)$. An early study compared serum lipid profile between 60 patients with chronic, painful mid portion Achilles tendinopathy to 60 sex, age and BMI matched controls (5). The participants with Achilles tendinopathy displayed evidence of dyslipidemia namely, elevated triglyceride levels, lower percentage HDL-C, and higher TG/HDL-C ratio. This study added to existing knowledge that lipid deposition preferentially affects aging tendon $(49,50)$, and cholesterol levels are high in patients who rupture their Achilles tendon (51). More recently we have discovered that lipid profile is associated with risk of developing rotator cuff injury (52) as well as surgical outcomes (53).

A systematic review and meta-analysis of 17 studies indicated that there was significantly higher total cholesterol, low-density lipoprotein cholesterol and triglyceride and lower high-density lipoprotein cholesterol in individuals with tendon pain/abnormality (7). The review also identified a significant positive correlation between tendon thickness and cholesterol among healthy individuals, in two of the three studies that reported these data. In individuals with familial hypercholesterolemia, there is a strong correlation between cholesterol year score and Achilles tendon thickness $(54,55)$.

Lipid abnormalities adversely affect the mechanical properties of tendon (56). Cholesterol accumulates within tendon tissue where it disrupts the architecture of the collagen matrix (57). There is evidence that cholesterol accumulation in the tendon is predominantly in the form of cholesterol esters (58), which is a biologically inert form (59). This may be a strategy to reduce the cytotoxic effect of cholesterol overload within tendon (60). A recent study of Achilles tendon biopsies showed unique patterns of apolipoprotein A1 in those from tendinopathy sufferers (61). Apolipoprotein A1 is the main protein in the high-density lipoprotein cholesterol complex, which is essential for reverse cholesterol transport (62). As such, this study hypothesized that dysfunction of reverse cholesterol transport may contribute to cholesterol overload in tendon.

Elevated cholesterol levels are commonly managed with statin medication. Interestingly, there appears to be a link between use of these drugs with tendinopathy and tendon rupture (8). It has also been pointed out that those who are prescribed statins have been exposed to high cholesterol levels for a number of years, and this preceding exposure could partly explain the link with the statin medication (5).

In summary, dyslipidemia is a feature of both glucocorticoid excess and tendinopathy. There are plausible molecular mechanisms whereby cholesterol excess can directly have a negative effect of tendon.

\section{Insulin resistance and type 2 diabetes}

Insulin resistance, the primary metabolic defect underpinning type 2 diabetes, is induced by chronic glucocorticoid excess $(15,20)$. This effect is driven by increased glucose production in the liver and reduce glucose uptake in skeletal muscle and adipose tissue (63). Glucocorticoid excess increases abdominal fat accumulation, which releases various cytokines. In particular, IL-1beta, IL-6 and TNF-alpha are implicated in driving insulin resistance (64). These cytokines have also been implicated in tendon disease (65) demonstrating the ability of these cytokines to cause both systemic and tendon disease.

Glucocorticoid excess affects all major peripheral tissues involved in glucose regulation $(20,66)$. Furthermore, significant overlap exists between these pathways and those leading to visceral adiposity and dyslipidemia. This is illustrated by both mechanistic studies (66) and the high rate of uncontrolled type 2 diabetes among individuals with Cushing's syndrome (23).

Insulin resistance and type 2 diabetes are associated with tendinopathy and tendon rupture $(5,6,67,68)$. A systematic review and meta-analysis of 31 studies identified an association between diabetes and tendinopathy. Tendinopathy was more common in individuals with diabetes and vice versa, and diabetes sufferers with tendinopathy have a longer duration of diabetes than those with diabetes but not tendinopathy (6). Furthermore, a recent population-based study of more than 58,000 individuals with diabetes and 
117,000 controls observed a hazard ratio of 1.56 (95\% CI 1.25 to 1.93) for rotator cuff surgery following adjustment for other risk factors (69). Worse treatment outcomes are found among people with diabetes following treatment of trigger finger (70), and a range of other tendon injuries (71). Recently it was shown that the metabolic syndrome affects treatment outcomes for lateral elbow tendinopathy (72).

One mechanism linking diabetes and tendinopathy may be increased tendon stiffness associated with collagen cross linking (73). The generation of cross links is rapidly accelerated in the presence of high glucose levels such as is seen in insulin resistance and type 2 diabetes (74). The mechanical properties of Achilles tendons obtained following amputations for non-healing diabetic ulcers were compared with Achilles tendons obtained following amputations for non-diabetes related causes (e.g. trauma, malignancy) (75). The non-diabetic tendons had superior mechanical properties including Young's modulus (elasticity), stiffness, and maximum load (75). Similar findings were seen in the patellar tendons of dogs following long-term insulin therapy for diabetes (76). There is also evidence that high glucose levels may affect tendon structure through changes in proteoglycan (77) and metalloproteinase levels (78).

As well as the indirect connection of glucocorticoid excess to tendinopathy via diabetes, there are also direct effects. Glucocorticoid exposure may interact with various facets of diabetes to amplify tendon damage. For example, in rats, expression of the receptor for advanced glycation end products (RAGE) on mast cells is enhanced by glucocorticoid exposure (79). There may be interactions between the higher levels of AGE in diabetes (74), higher RAGE expression on mast cells, and higher mast cell expression in tendinopathy (80).

Another avenue of interest is the effect that glucocorticoids have on glutamate receptors. Glutamate activates the ionotropic receptor $\mathrm{N}$-methyl-D-aspartate (NMDA). Glutamate levels are elevated in chronic tendinopathy (81) and NMDA receptors are seen on abnormal nerve fibres, tenocytes, and blood vessels in tendinopathy (82). Furthermore, stimulation of glutamate receptors with both glutamate and NMDAR (separately) in tendon derived cells reduced the expression of scleraxis (83), which is an important transcription factor and marker of tendon-like cells. Acute stress and glucocorticoid exposure cause transient glutamate release in a range of brain regions in animal studies (84), and also increases membrane expression of NMDA receptors. Other studies indicate that glucocorticoid exposure potentiates neuroexcitotoxic effects related to overstimulation of NMDA receptors (85). Rotator cuff tendon biopsies taken before and 7 weeks after glucocorticoid injection show a large increase in the proportion of cells positive for NMDA receptor subtype 1 staining that was not seen over the same period in response tendon repair surgery (36). These findings are supported by a recent study showing that 24-week NMDA receptor antagonist administration partly reversed the adverse effects of long-term glucocorticoid treatment on the CA3 region of the hippocampus (86). Together these studies indicate that glutamate and NMDA receptors are involved in tendinopathy and that glucocorticoid exposure both induces glutamate release and enhances stimulation of NMDA receptors leading to neuroexcitotoxic effects.

In summary, the bulk of the evidence linking glucocorticoid excess and tendinopathy is via an indirect pathway. That is, glucocorticoid excess promotes insulin resistance and type 2 diabetes, which then adversely affect tendon. There is also some preliminary evidence that glucocorticoid may directly affect tendon via RAGE expression on mast cells or via NMDA receptors on tenocytes.

\section{Does improving an individual's metabolic state reduce their tendinopathy risk?}

No studies have directly examined whether improving an individual's metabolic state reduces the risk of tendinopathy or aids recovery from tendon injury. However, authors have concluded that this makes sense from first principles $(6,71)$. A recent systematic review looked at the effect of female sex hormone supplementation on tendon molecular, mechanical, and morphological traits (87). It was found that the evidence was contradictory, and the studies were generally of low quality. We anticipate the soon to be released results of a randomized controlled trial of hormonal therapy, exercise, or both, among post-menopausal women with greater trochanteric pain syndrome (88).

There is undoubtedly a reduction in musculoskeletal pain following bariatric surgery induced weight loss (89). Without further research the relative contributions of reduced mechanical loading, improved metabolic state, improved mood, increased physical activity, and reduced pain sensitization to this effect is unclear (90). 


\section{Conclusion}

A wealth of recent literature confirms the link that tendinopathy has with visceral adiposity, dyslipidemia, insulin resistance and diabetes (Table 1 ). There are a number of plausible pathways through which glucocorticoids might provide a connection between metabolic health and tendinopathy (Fig. 1). These same physiological states are intimately related to glucocorticoid excess, as most vividly demonstrated in Cushing's syndrome. The harmful effects that exogenous corticosteroids produce in tendons on a structural and immunohistological level are well documented. The confluence of factors is marked, and the co-occurrence of multiple tendon injuries in large datasets strongly suggests shared risk factors (e.g. genetic or metabolic) (91). There is a growing body of research into the effects of endogenous hormones on tendons.

Many people live a stressful life, which is connected with elevated cortisol levels (92). Whilst there is an established evidence base for the link between metabolic disorders and tendon problems in patients with Cushing's syndrome, there are no data on cortisol levels in tendinopathy. This is potentially an avenue for further research.

Cortisol levels can be reliably measured using saliva samples (93). This method of measuring physiological levels of this hormone could be utilized to measure cortisol levels in tendinopathy patients and comparing these levels with age-matched controls to assess whether this hormone is another factor or indeed a central, connecting factor in the growing evidence base regarding the causation of tendinopathy.

\section{Declaration of interest}

The authors declare that there is no conflict of interest that could be perceived as prejudicing the impartiality of this review.

\section{Funding}

This work did not receive any specific grant from any funding agency in the public, commercial or not-for-profit sector.

\section{References}

1 Gaida JE, Ashe MC, Bass SL \& Cook JL. Is adiposity an underrecognized risk factor for tendinopathy? A systematic review. Arthritis and Rheumatism 200961 840-849. (https://doi.org/10.1002/ art.24518)

2 Ferretti A, Puddu G, Mariani PP \& Neri M. Jumper's knee: an epidemiological study of volleyball players. Physician and Sportsmedicine 198412 97-106. (https://doi.org/10.1080/00913847.1 984.11701970)
3 Nielsen RØ, Parner ET, Nohr EA, Sorensen H, Lind M \& Rasmussen S. Excessive progression in weekly running distance and risk of running-related injuries: an association which varies according to type of injury. Journal of Orthopaedic and Sports Physical Therapy 2014 44 739-747. (https://doi.org/10.2519/jospt.2014.5164)

4 Rolf C \& Movin T. Etiology, histopathology, and outcome of surgery in achillodynia. Foot and Ankle International 199718 565-569. (https://doi.org/10.1177/107110079701800906)

5 Gaida JE, Alfredson L, Kiss ZS, Wilson AM, Alfredson H \& Cook JL. Dyslipidemia in Achilles tendinopathy is characteristic of insulin resistance. Medicine and Science in Sports and Exercise 200941 1194-1197. (https://doi.org/10.1249/MSS.0b013e31819794c3) 6 Ranger TA, Wong AM, Cook JL \& Gaida JE. Is there an association between tendinopathy and diabetes mellitus? A systematic review with meta-analysis. British Journal of Sports Medicine $2016 \mathbf{5 0}$ 982-989. (https://doi.org/10.1136/bjsports-2015-094735)

7 Tilley BJ, Cook JL, Docking SI \& Gaida JE. Is higher serum cholesterol associated with altered tendon structure or tendon pain? A systematic review. British Journal of Sports Medicine 201549 1504-1509. (https://doi.org/10.1136/bjsports-2015-095100)

8 Teichtahl AJ, Brady SR, Urquhart DM, Wluka AE, Wang Y, Shaw JE \& Cicuttini FM. Statins and tendinopathy: a systematic review. Medical Journal of Australia 2016204 115-21.e1. (https://doi.org/10.5694/ mja15.00806)

9 Gaida JE, Alfredson H, Kiss ZS, Bass SL \& Cook JL. Asymptomatic Achilles tendon pathology is associated with a central fat distribution in men and a peripheral fat distribution in women: a cross sectional study of 298 individuals. BMC Musculoskeletal Disorders 20101141. (https://doi.org/10.1186/1471-2474-11-41)

10 Jewson JL, Lambert EA, Docking S, Storr M, Lambert GW \& Gaida JE. Pain duration is associated with increased muscle sympathetic nerve activity in patients with Achilles tendinopathy. Scandinavian Journal of Medicine and Science in Sports 201727 1942-1949. (https://doi. org/10.1111/sms.12820)

11 Jewson JL, Lambert GW, Storr M \& Gaida JE. The sympathetic nervous system and tendinopathy: a systematic review. Sports Medicine 201545 727-743. (https://doi.org/10.1007/s40279-0140300-9)

12 Kanayama G, DeLuca J, Meehan WP, 3rd, Hudson JI, Isaacs S, Baggish A, Weiner R, Micheli L \& Pope HG, Jr. Ruptured tendons in anabolic-androgenic steroid users: a cross-sectional cohort study. American Journal of Sports Medicine 201543 2638-2644. (https://doi. org/10.1177/0363546515602010)

13 Oakley RH \& Cidlowski JA. The biology of the glucocorticoid receptor: new signaling mechanisms in health and disease. Journal of Allergy and Clinical Immunology 2013132 1033-1044. (https://doi. org/10.1016/j.jaci.2013.09.007)

14 Walker JJ, Spiga F, Waite E, Zhao Z, Kershaw Y, Terry JR \& Lightman SL. The origin of glucocorticoid hormone oscillations. PLoS Biology 201210 e1001341. (https://doi.org/10.1371/journal. pbio.1001341)

15 Sacta MA, Chinenov Y \& Rogatsky I. Glucocorticoid signaling: an update from a genomic perspective. Annual Review of Physiology 201678 155-180. (https://doi.org/10.1146/annurevphysiol-021115-105323)

16 Lightman SL \& Conway-Campbell BL. The crucial role of pulsatile activity of the HPA axis for continuous dynamic equilibration. Nature Reviews: Neuroscience 201011 710-718. (https://doi.org/10.1038/ nrn2914)

17 Kalsbeek A, Scheer FA, Perreau-Lenz S, La Fleur SE, Yi CX, Fliers E $\&$ Buijs RM. Circadian disruption and SCN control of energy metabolism. FEBS Letters 2011585 1412-1426. (https://doi. org/10.1016/j.febslet.2011.03.021)

18 Herman JP, McKlveen JM, Ghosal S, Kopp B, Wulsin A, Makinson R, Scheimann J \& Myers B. Regulation of the hypothalamic-pituita https://ec.bioscientifica.com https://doi.org/10.1530/EC-19-0555 (c) 2020 The authors Published by Bioscientifica Ltd
This work is licensed under a Creative Commons Attribution-NonCommercial-NoDerivatives 4.0 Anternationab sicense.ifica.com at $04 / 26 / 2023$ 08:38:42AM 
ry-adrenocortical stress response. Comprehensive Physiology 20166 603-621. (https://doi.org/10.1002/cphy.c150015)

19 Oster H, Challet E, Ott V, Arvat E, de Kloet ER, Dijk DJ, Lightman S, Vgontzas A \& Van Cauter E. The functional and clinical significance of the 24-hour rhythm of circulating glucocorticoids. Endocrine Reviews 201738 3-45. (https://doi.org/10.1210/er.2015-1080)

20 Geer EB, Islam J \& Buettner C. Mechanisms of glucocorticoidinduced insulin resistance: focus on adipose tissue function and lipid metabolism. Endocrinology and Metabolism Clinics of North America 201443 75-102. (https://doi.org/10.1016/j.ecl.2013.10.005)

21 Steiner JL, Bardgett ME, Wolfgang L, Lang CH \& Stocker SD. Glucocorticoids attenuate the central sympathoexcitatory actions of insulin. Journal of Neurophysiology 2014112 2597-2604. (https://doi. org/10.1152/jn.00514.2014)

22 Cain DW \& Cidlowski JA. Immune regulation by glucocorticoids. Nature Reviews: Immunology 201717 233-247. (https://doi. org/10.1038/nri.2017.1)

23 Lacroix A, Feelders RA, Stratakis CA \& Nieman LK. Cushing's syndrome. Lancet 2015386 913-927. (https://doi.org/10.1016/ S0140-6736(14)61375-1)

24 Mousa A, Jones S, Toft A \& Perros P. Spontaneous rupture of Achilles tendon: missed presentation of Cushing's syndrome. BMJ 1999319 560-561. (https://doi.org/10.1136/bmj.319.7209.560)

25 Blanco I, Krahenbuhl S \& Schlienger RG. Corticosteroid-associated tendinopathies: an analysis of the published literature and spontaneous pharmacovigilance data. Drug Safety 200528 633-643. (https://doi.org/10.2165/00002018-200528070-00005)

26 Spoendlin J, Meier C, Jick SS \& Meier CR. Oral and inhaled glucocorticoid use and risk of Achilles or biceps tendon rupture: a population-based case-control study. Annals of Medicine 201547 492-498. (https://doi.org/10.3109/07853890.2015.1074272)

27 Taguchi T, Kubota M, Saito M, Hattori H, Kimura T \& Marumo K. Quantitative and qualitative change of collagen of Achilles tendons in rats with systemic administration of glucocorticoids. Foot and Ankle International 201637 327-333. (https://doi. org/10.1177/1071100715613138)

28 Dean BJ \& Carr AJ. The effects of glucocorticoid on tendon and tendon derived cells. Advances in Experimental Medicine and Biology 2016920 239-246. (https://doi.org/10.1007/978-3-319-33943-6_23)

29 Spang C, Chen J \& Backman LJ. The tenocyte phenotype of human primary tendon cells in vitro is reduced by glucocorticoids. BMC Musculoskeletal Disorders 201617 467. (https://doi.org/10.1186/ s12891-016-1328-9)

30 Min K, Lee JM, Kim MJ, Jung SY, Kim KS, Lee S \& Choi YS. Restoration of cellular proliferation and characteristics of human tenocytes by vitamin D. Journal of Orthopaedic Research 201937 2241-2248. (https://doi.org/10.1002/jor.24352)

31 Dean BJ, Lostis E, Oakley T, Rombach I, Morrey ME \& Carr AJ. The risks and benefits of glucocorticoid treatment for tendinopathy: a systematic review of the effects of local glucocorticoid on tendon. Seminars in Arthritis and Rheumatism 201443 570-576. (https://doi. org/10.1016/j.semarthrit.2013.08.006)

32 Khan KM, Cook JL, Kannus P, Maffulli N \& Bonar SF. Time to abandon the "tendinitis" myth. BMJ 2002324 626-627. (https://doi. org/10.1136/bmj.324.7338.626)

33 Rees JD, Stride M \& Scott A. Tendons--time to revisit inflammation. British Journal of Sports Medicine 201448 1553-1557. (https://doi. org/10.1136/bjsports-2012-091957)

34 Mosca MJ, Rashid MS, Snelling SJ, Kirtley S, Carr AJ \& Dakin SG. Trends in the theory that inflammation plays a causal role in tendinopathy: a systematic review and quantitative analysis of published reviews. BMJ Open Sport and Exercise Medicine 20184 e000332. (https://doi.org/10.1136/bmjsem-2017-000332)

35 Pingel J, Petersen MC, Fredberg U, Kjaer SG, Quistorff B, Langberg H \& Hansen JB. Inflammatory and metabolic alterations of Kager's fat pad in chronic Achilles tendinopathy. PLOS ONE 201510 e0127811. (https://doi.org/10.1371/journal.pone.0127811)

36 Dean BJ, Franklin SL, Murphy RJ, Javaid MK \& Carr AJ. Glucocorticoids induce specific ion-channel-mediated toxicity in human rotator cuff tendon: a mechanism underpinning the ultimately deleterious effect of steroid injection in tendinopathy? British Journal of Sports Medicine 201448 1620-1626. (https://doi. org/10.1136/bjsports-2013-093178)

37 Bisset L, Beller E, Jull G, Brooks P, Darnell R \& Vicenzino B. Mobilisation with movement and exercise, corticosteroid injection, or wait and see for tennis elbow: randomised trial. BMJ 2006333 939. (https://doi.org/10.1136/bmj.38961.584653.AE)

38 MacMahon PJ, Eustace SJ \& Kavanagh EC. Injectable corticosteroid and local anesthetic preparations: a review for radiologists. Radiology 2009252 647-661. (https://doi.org/10.1148/radiol.2523081929)

39 Coombes BK, Bisset L \& Vicenzino B. Efficacy and safety of corticosteroid injections and other injections for management of tendinopathy: a systematic review of randomised controlled trials. Lancet 2010376 1751-1767. (https://doi.org/10.1016/S01406736(10)61160-9)

40 Nyyssonen T, Lantto I, Luthje P, Selander T \& Kroger H. Drug treatments associated with Achilles tendon rupture. A case-control study involving 1118 Achilles tendon ruptures. Scandinavian Journal of Medicine and Science in Sports 201828 2625-2629. (https://doi. org/10.1111/sms.13281)

41 van der Linden PD, Sturkenboom MC, Herings RM, Leufkens HM, Rowlands S \& Stricker BH. Increased risk of Achilles tendon rupture with quinolone antibacterial use, especially in elderly patients taking oral corticosteroids. Archives of Internal Medicine 2003163 1801-1807. (https://doi.org/10.1001/archinte.163.15.1801)

42 Clark SC, Jones MW, Choudhury RR \& Smith E. Bilateral patellar tendon rupture secondary to repeated local steroid injections. Journal of Accident and Emergency Medicine 199512 300-301. (https://doi. org/10.1136/emj.12.4.300)

43 Ford LT \& DeBender J. Tendon rupture after local steroid injection. Southern Medical Journal 197972 827-830. (https://doi. org/10.1097/00007611-197907000-00019)

44 Chen SK, Lu CC, Chou PH, Guo LY \& Wu WL. Patellar tendon ruptures in weight lifters after local steroid injections. Archives of Orthopaedic and Trauma Surgery 2009129 369-372. (https://doi. org/10.1007/s00402-008-0655-1)

45 Haraldsson BT, Langberg H, Aagaard P, Zuurmond AM, van El B, Degroot J, Kjaer M \& Magnusson SP. Corticosteroids reduce the tensile strength of isolated collagen fascicles. American Journal of Sports Medicine 200634 1992-1997. (https://doi. org/10.1177/0363546506290402)

46 Carmienke S, Freitag MH, Pischon T, Schlattmann P, Fankhaenel T, Goebel H \& Gensichen J. General and abdominal obesity parameters and their combination in relation to mortality: a systematic review and meta-regression analysis. European Journal of Clinical Nutrition 201367 573-585. (https://doi.org/10.1038/ejcn.2013.61)

47 Mathis D. Immunological goings-on in visceral adipose tissue. Cell Metabolism 201317 851-859. (https://doi.org/10.1016/j. cmet.2013.05.008)

48 Arnaldi G, Scandali VM, Trementino L, Cardinaletti M, Appolloni G \& Boscaro M. Pathophysiology of dyslipidemia in Cushing's syndrome. Neuroendocrinology 201092 (Supplement 1) 86-90. (https://doi.org/10.1159/000314213)

49 Adams CW, Bayliss OB, Baker RW, Abdulla YH \& Hunter-Craig CJ. Lipid deposits in ageing human arteries, tendons and fascia. Atherosclerosis 197419 429-440. (https://doi.org/10.1016/s00219150(74)80007-9)

50 Finlayson R \& Woods SJ. Lipid in the Achilles tendon. A comparative study. Atherosclerosis 197521 371-389. (https://doi. org/10.1016/0021-9150(75)90050-7) https://ec.bioscientifica.com https://doi.org/10.1530/EC-19-0555
(C) 2020 The authors Published by Bioscientifica Ltd
This work is licensed under a Creative Commons Attribution-NonCommercial-NoDerivatives 4.0 Internationab License.ifica com at $04 / 26 / 2023$ 08:38:42AM 
51 Ozgurtas T, Yildiz C, Serdar M, Atesalp S \& Kutluay T. Is high concentration of serum lipids a risk factor for Achilles tendon rupture? Clinica Chimica Acta 2003331 25-28. (https://doi. org/10.1016/s0009-8981(03)00075-5)

52 Lin TT, Lin CH, Chang CL, Chi CH, Chang ST \& Sheu WH. The effect of diabetes, hyperlipidemia, and statins on the development of rotator cuff disease: a nationwide, 11-year, longitudinal, populationbased follow-up study. American Journal of Sports Medicine 201543 2126-2132. (https://doi.org/10.1177/0363546515588173)

53 Cancienne JM, Brockmeier SF, Rodeo SA \& Werner BC. Perioperative serum lipid status and statin use affect the revision surgery rate after arthroscopic rotator cuff repair. American Journal of Sports Medicine 201745 2948-2954. (https://doi.org/10.1177/0363546517717686)

54 Schmidt HH, Hill S, Makariou EV, Feuerstein IM, Dugi KA \& Hoeg JM. Relation of cholesterol-year score to severity of calcific atherosclerosis and tissue deposition in homozygous familial hypercholesterolemia. American Journal of Cardiology 199677 575-580. (https://doi. org/10.1016/s0002-9149(97)89309-5)

55 Zech LA, Jr \& Hoeg JM. Correlating corneal arcus with atherosclerosis in familial hypercholesterolemia. Lipids in Health and Disease 20087 7. (https://doi.org/10.1186/1476-511X-7-7)

56 Beason DP, Hsu JE, Marshall SM, McDaniel AL, Temel RE, Abboud JA \& Soslowsky LJ. Hypercholesterolemia increases supraspinatus tendon stiffness and elastic modulus across multiple species. Journal of Shoulder and Elbow Surgery 201322 681-686. (https://doi. $\operatorname{org} / 10.1016 /$ j.jse.2012.07.008)

57 Jozsa L, Reffy A \& Balint JB. The pathogenesis of tendolipomatosis; an electron microscopical study. International Orthopaedics 19847 251-255. (https://doi.org/10.1007/bf00266836)

58 von Bahr S, Movin T, Papadogiannakis N, Pikuleva I, Ronnow P, Diczfalusy U \& Bjorkhem I. Mechanism of accumulation of cholesterol and cholestanol in tendons and the role of sterol 27-hydroxylase (CYP27A1). Arteriosclerosis, Thrombosis, and Vascular Biology 200222 1129-1135. (https://doi.org/10.1161/01. atv.0000022600.61391.a5)

59 Tulenko TN \& Sumner AE. The physiology of lipoproteins. Journal of Nuclear Cardiology 20029 638-649. (https://doi.org/10.1067/ mnc.2002.128959)

60 Tabas I. Consequences of cellular cholesterol accumulation: basic concepts and physiological implications. Journal of Clinical Investigation 2002110 905-911. (https://doi.org/10.1172/JCI16452)

61 Gaida JE, Alfredson H, Scott A, Mousavizadeh R \& Forsgren S. Apolipoprotein A1 (Apo-A1) distribution pattern in the human Achilles tendon. Scandinavian Journal of Medicine and Science in Sports 201828 1506-1513. (https://doi.org/10.1111/sms.13051)

62 Tall AR. An overview of reverse cholesterol transport. European Heart Journal 199819 (Supplement A) A31-A35. (https://doi. org/10.1016/0021-9150(94)94350-8)

63 Kuo T, McQueen A, Chen TC \& Wang JC. Regulation of glucose homeostasis by glucocorticoids. Advances in Experimental Medicine and Biology 2015872 99-126. (https://doi.org/10.1007/978-1-4939-28958_5)

64 Esser N, Legrand-Poels S, Piette J, Scheen AJ \& Paquot N. Inflammation as a link between obesity, metabolic syndrome and type 2 diabetes. Diabetes Research and Clinical Practice 2014105 141-150. (https://doi.org/10.1016/j.diabres.2014.04.006)

65 Morita W, Dakin SG, Snelling SJB \& Carr AJ. Cytokines in tendon disease: a systematic review. Bone and Joint Research 20176 656-664. (https://doi.org/10.1302/2046-3758.612.BJR-2017-0112.R1)

66 Scaroni C, Zilio M, Foti M \& Boscaro M. Glucose metabolism abnormalities in Cushing syndrome: from molecular basis to clinical management. Endocrine Reviews 201738 189-219. (https://doi. org/10.1210/er.2016-1105)

67 de Jonge S, Rozenberg R, Vieyra B, Stam HJ, Aanstoot HJ, Weinans H, van Schie HT \& Praet SF. Achilles tendons in people with type 2 diabetes show mildly compromised structure: an ultrasound tissue characterisation study. British Journal of Sports Medicine 201549 995-999. (https://doi.org/10.1136/bjsports-2014-093696)

68 Zakaria MH, Davis WA \& Davis TM. Incidence and predictors of hospitalization for tendon rupture in type 2 diabetes: the fremantle diabetes study. Diabetic Medicine 201431 425-430. (https://doi. org/10.1111/dme.12344)

69 Huang SW, Wang WT, Chou LC, Liou TH, Chen YW \& Lin HW. Diabetes mellitus increases the risk of rotator cuff tear repair surgery: a population-based cohort study. Journal of Diabetes and Complications 201630 1473-1477. (https://doi.org/10.1016/j. jdiacomp.2016.07.015)

70 Kameyama M, Funae O, Meguro S \& Atsumi Y. HbA1c values determine the outcome of intrasheath injection of triamcinolone for diabetic flexor tenosynovitis. Diabetes Care 200629 2512-2514. (https://doi.org/10.2337/dc06-0852)

71 Rees J, Gaida JE, Silbernagel KG, Zwerver J, Anthony JS \& Scott A. Rehabilitation of tendon problems in patients with diabetes mellitus. Advances in Experimental Medicine and Biology 2016920 199-208. (https://doi.org/10.1007/978-3-319-33943-6_19)

72 Roh YH, Oh M, Noh JH, Gong HS \& Baek GH. Effect of metabolic syndrome on the functional outcome of corticosteroid injection for lateral epicondylitis: retrospective matched case-control study. Scientific Reports 20177 10845. (https://doi.org/10.1038/s41598-01711179-z)

73 Couppe C, Svensson RB, Kongsgaard M, Kovanen V, Grosset JF, Snorgaard O, Bencke J, Larsen JO, Bandholm T, Christensen TM, et al. Human Achilles tendon glycation and function in diabetes. Journal of Applied Physiology 2016120 130-137. (https://doi.org/10.1152/ japplphysiol.00547.2015)

74 Vogt BW, Schleicher ED \& Wieland OH. epsilon-amino-lysine-bound glucose in human tissues obtained at autopsy. Increase in diabetes mellitus. Diabetes 198231 1123-1127. (https://doi.org/10.2337/ diacare.31.12.1123)

75 Guney A, Vatansever F, Karaman I, Kafadar IH, Oner M \& Turk CY. Biomechanical properties of Achilles tendon in diabetic vs. non-diabetic patients. Experimental and Clinical Endocrinology and Diabetes 2015123 428-432. (https://doi. org/10.1055/s-0035-1549889)

76 Lancaster RL, Haut RC \& DeCamp CE. Changes in the mechanical properties of patellar tendon preparations of spontaneously diabetic dogs under long-term insulin therapy. Journal of Biomechanics 1994 27 1105-1108. (https://doi.org/10.1016/0021-9290(94)90228-3)

77 Burner T, Gohr C, Mitton-Fitzgerald E \& Rosenthal AK. Hyperglycemia reduces proteoglycan levels in tendons. Connective Tissue Research 201253 535-541. (https://doi.org/10.3109/03008207. 2012.710670)

78 Tsai WC, Liang FC, Cheng JW, Lin LP, Chang SC, Chen HH \& Pang JH. High glucose concentration up-regulates the expression of matrix metalloproteinase- 9 and -13 in tendon cells. BMC Musculoskeletal Disorders 201314 255. (https://doi.org/10.1186/14712474-14-255)

79 Santoro T, Azevedo CT, E Silva PMR, Martins MA \& Carvalho VF. Glucocorticoids decrease the numbers and activation of mast cells by inducing the transactivation receptors of AGEs. Journal of Leukocyte Biology 2019105 131-142. (https://doi.org/10.1002/JLB.3A0917364RR)

80 Scott A, Lian Ø, Bahr R, Hart DA, Duronio V \& Khan KM. Increased mast cell numbers in human patellar tendinosis: correlation with symptom duration and vascular hyperplasia. British Journal of Sports Medicine 200842 753-757. (https://doi.org/10.1136/ bjsm.2007.040212)

81 Alfredson $\mathrm{H}$, Thorsen $\mathrm{K} \&$ Lorentzon R. In situ microdialysis in tendon tissue: high levels of glutamate, but not prostaglandin E2 in chronic Achilles tendon pain. Knee Surgery, Sports Traumatology, Arthroscopy 19997 378-381. (https://doi.org/10.1007/ s001670050184) 
82 Schizas N, Lian Ø, Frihagen F, Engebretsen L, Bahr R \& Ackermann PW. Coexistence of up-regulated NMDA receptor 1 and glutamate on nerves, vessels and transformed tenocytes in tendinopathy. Scandinavian Journal of Medicine and Science in Sports 201020 208-215. (https://doi.org/10.1111/j.16000838.2009.00913.x)

83 Spang C, Backman LJ, Le Roux S, Chen J \& Danielson P. Glutamate signaling through the NMDA receptor reduces the expression of scleraxis in plantaris tendon derived cells. BMC Musculoskeletal Disorders 201718 218. (https://doi.org/10.1186/s12891-017-1575-4)

84 Popoli M, Yan Z, McEwen BS \& Sanacora G. The stressed synapse: the impact of stress and glucocorticoids on glutamate transmission. Nature Reviews: Neuroscience 201113 22-37. (https://doi.org/10.1038/ nrn3138)

85 Xiao L, Feng C \& Chen Y. Glucocorticoid rapidly enhances NMDAevoked neurotoxicity by attenuating the NR2A-containing NMDA receptor-mediated ERK1/2 activation. Molecular Endocrinology 2010 24 497-510. (https://doi.org/10.1210/me.2009-0422)

86 Brown ES, Kulikova A, Van Enkevort E, Nakamura A, Ivleva EI, Tustison NJ, Roberts J, Yassa MA, Choi C, Frol A, et al. A randomized trial of an NMDA receptor antagonist for reversing corticosteroid effects on the human hippocampus. Neuropsychopharmacology 2019 44 2263-2267. (https://doi.org/10.1038/s41386-019-0430-8)

87 Ganderton C, Semciw A, Cook J \& Pizzari T. The effect of female sex hormone supplementation on tendon in pre and postmenopausal women: a systematic review. Journal of Musculoskeletal and Neuronal Interactions $2016 \mathbf{1 6} 92-104$
88 Ganderton C, Semciw A, Cook J \& Pizzari T. Does menopausal hormone therapy (MHT), exercise or a combination of both, improve pain and function in post-menopausal women with greater trochanteric pain syndrome (GTPS)? A randomised controlled trial. BMC Women's Health 201616 32. (https://doi.org/10.1186/s12905016-0311-9)

89 King WC, Chen JY, Belle SH, Courcoulas AP, Dakin GF, Elder KA, Flum DR, Hinojosa MW, Mitchell JE, Pories WJ, et al. Change in pain and physical function following bariatric surgery for severe obesity. JAMA 2016315 1362-1371. (https://doi.org/10.1001/ jama.2016.3010)

90 Stefanik JJ, Felson DT, Apovian CM, Niu J, Margaret Clancy M, LaValley MP \& Neogi T. Changes in pain sensitization after bariatric surgery. Arthritis Care and Research 201870 1525-1528. (https://doi. org/10.1002/acr.23513)

91 Titchener AG, White JJ, Hinchliffe SR, Tambe AA, Hubbard RB \& Clark DI. Comorbidities in rotator cuff disease: a case-control study. Journal of Shoulder and Elbow Surgery 201423 1282-1288. (https://doi. org/10.1016/j.jse.2013.12.019)

92 Lucassen PJ, Pruessner J, Sousa N, Almeida OF, Van Dam AM, Rajkowska G, Swaab DF \& Czeh B. Neuropathology of stress. Acta Neuropathologica 2014127 109-135. (https://doi.org/10.1007/ s00401-013-1223-5)

93 Strahler J, Skoluda N, Kappert MB \& Nater UM. Simultaneous measurement of salivary cortisol and alpha-amylase: application and recommendations. Neuroscience and Biobehavioral Reviews 201783 657-677. (https://doi.org/10.1016/j.neubiorev.2017.08.015)

Received in final form 13 January 2020

Accepted 21 January 2020

Accepted Manuscript published online 22 January 2020 (c) 2020 The authors Published by Bioscientifica Ltd
This work is licensed under a Creative Commons Attribution-NonCommercial-NoDerivatives 4.0 Internationab bicense ifica com at 04/26/2023 08:38:42Al 